\title{
Sciendo
}

Administration, vol. 70, no. 1 (2022), pp. 83-96

doi: 10.2478/admin-2022-0007

\section{State-owned enterprise sector, 2021}

\author{
Dónal Palcic \& Eoin Reeves* \\ Department of Economics, Kemmy Business School, \\ University of Limerick
}

\section{Overview 1}

The commercial state-owned enterprise (SOE) sector has operated under extremely challenging conditions in recent years. The Covid-19 pandemic had a significant negative impact on the financial performance of several SOEs in 2020, especially those operating in the aviation and public transport sectors. In addition, many companies continue to operate amid uncertainty around the effects of Brexit. Given the prominence of SOEs in transport and energy sectors, these companies will play an important part in the low-carbon transition and are devising strategic and investment plans accordingly.

Table 1 provides an overview of the basic financial performance of the main Irish SOEs for the 2020 financial year. As highlighted in previous reviews (Palcic \& Reeves, 2018, 2019, 2020, 2021), and despite the impact of the pandemic, the commercial SOE sector continues to make an important contribution to the Irish economy. Aggregate turnover for the thirteen companies included in Table 1 was equivalent to approximately 4.6 per cent of nominal modified gross national income (GNI*) in 2020, while aggregate employment amounted to over 38,000 people. In terms of investment, total capital

* ORCID: Dónal Palcic - http://orcid.org/0000-0003-4726-9640; Eoin Reeves http://orcid.org/0000-0003-4674-3152

1 The analysis and discussion presented in this review rely heavily on information provided in SOE annual reports and on SOE websites. 


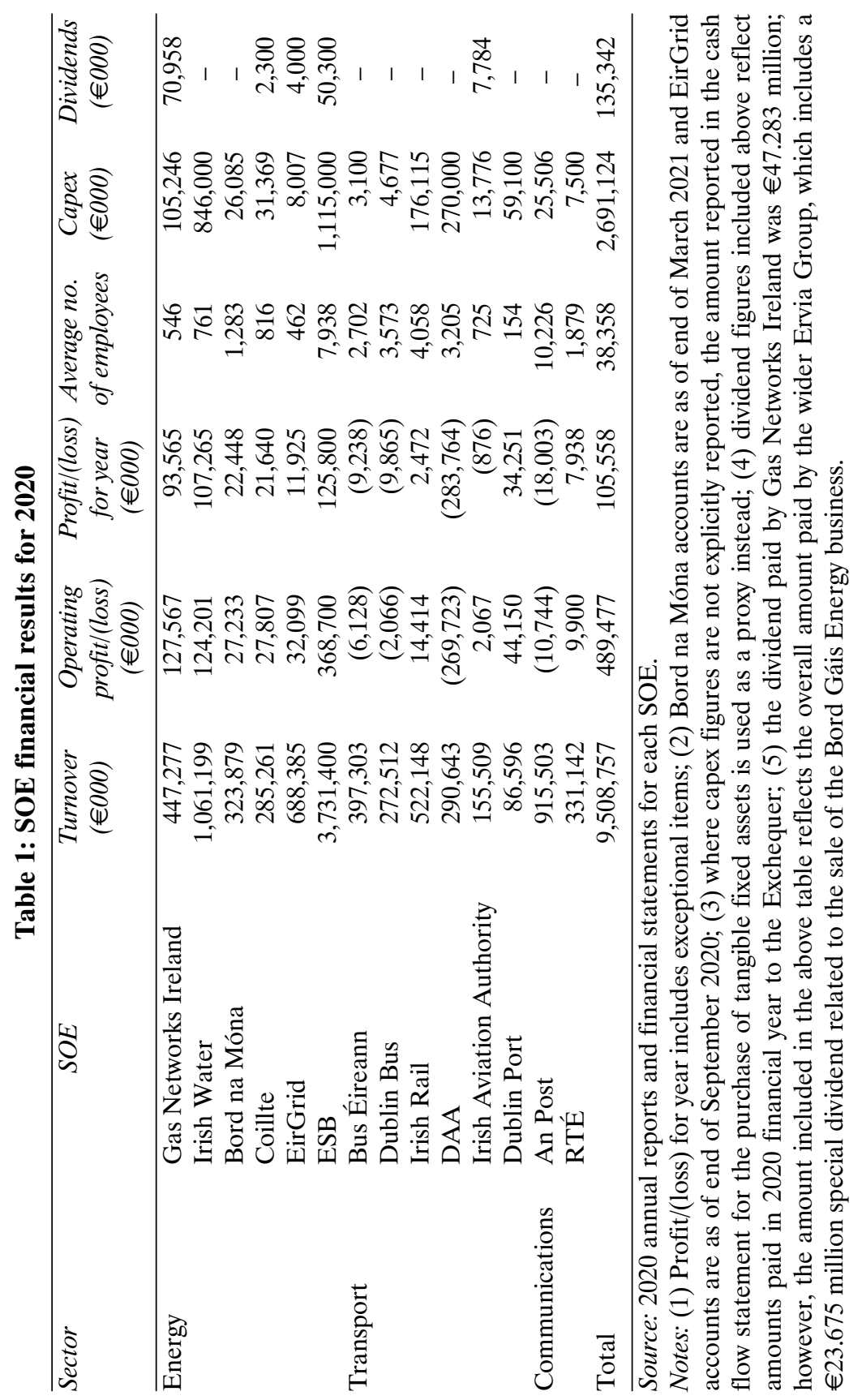


expenditure by the SOEs included in Table 1 was down slightly on the previous year but still amounted to just under $€ 2.7$ billion. The aggregate amount of dividends transferred to the Exchequer was almost half that of the previous year, with five SOEs contributing just over $€ 135$ million in dividends in 2020 .

All of the transport SOEs apart from Dublin Port reported net losses for 2020, as well as An Post, largely as a result of Covid-related exceptional costs. The remaining SOEs all recorded healthy operating and net profits considering the difficult trading environment some faced as a result of the pandemic and the continued impact of Brexit. The next section provides a brief summary of the factors underpinning the financial performance of each SOE in 2020 and some of the main developments in 2021.

\section{CIÉ Group - Bus Éireann, Iarnród Éireann and Dublin Bus}

The Covid-19 pandemic has had significant material impacts on the financial performance of the CIÉ Group due to a reduction in demand and the requirement to operate at reduced capacity due to social distancing requirements. During 2020 customer revenue fell by $€ 474$ million as overall passenger journey numbers fell by approximately 50 per cent. The financial challenges faced by the CIÉ Group due to the ongoing impact of the Covid-19 pandemic were highlighted by the group to the Oireachtas Committee on Transport and Communications Networks in April 2021. In addition, the group drew attention to challenges it faces in making changes to its two pension schemes. Reported deficits on the two schemes amounted to $€ 975$ million and planned changes aim at rectifying this deficit in order to meet the statutory minimum funding standard required by the Pensions Authority.

In 2020 the group launched its Sustainability Strategy with the stated aim of becoming a leader in climate action and using its expertise to accelerate Ireland's transition to a low-carbon economy. The group's 2020 annual report highlighted some early progress in achieving its sustainability objectives, including: progress on Dart+ and orders for additional rail fleet, an increase in hybrid bus vehicles in service, and the preparation for full battery electric vehicles. The group deployed the first hydrogen fuel cell electric vehicle (FCEV) into operation in Ireland in 2020 and are preparing to deploy three National Transport Authority (NTA) double-deck FCEVs into service (CIÉ Group, 2021). 


\section{Dublin Bus}

Dublin Bus incurred a deficit of $€ 9.8$ million ( $€ 3.8$ million before exceptional costs) in 2020 compared to a surplus of $€ 1.4$ million ( $€ 6.8$ million before exceptional costs) in 2019. This deterioration was mainly attributable to a 51 per cent reduction in customer journeys as a result of the pandemic, which resulted in annual revenues of $€ 125.1$ million compared to $€ 263.0$ million in 2019. Although total direct costs decreased by $€ 15.1$ million, the company incurred additional costs for the introduction of safety measures associated with Covid-19, such as inter-trip cleaning for vehicles and other safety-related expenditure. Savings were achieved, however, from service changes associated with Covid-19, including changes in schedules in accordance with the level of demand and capacity restrictions at each level of the government's response to the pandemic.

The public service obligation (PSO) payment received by Dublin Bus increased to $€ 125$ million, which was significantly higher than the $€ 30$ million received in 2019. In relation to PSO services, it should be noted that from January 2021 Dublin Bus transitioned to a gross cost contract in which the NTA assumes responsibility for revenues on PSO services. The 2020 results also reflect the decision of the NTA to retain costs in relation to the Integrated Ticketing System within the NTA.

The BusConnects network plan for Dublin, published by the NTA in September 2020, got underway over the summer of 2021. The first services of the redesigned bus network for Dublin began operating from Howth and Malahide in June 2021. However, pandemic restrictions had slowed the implementation, which aims to create sixteen new 'core bus corridors' and segregated cycle lanes around the city.

\section{Bus Éireann}

Having reported net profits in 2019 (for the first time since 2013), Bus Éireann reported a deficit of $€ 9.2$ million in 2020 as the company experienced a massive reduction in passenger journeys from 89.4 million to 51.7 million between 2019 and 2020. The decision to maintain essential services contributed to a depletion of the net asset position of the company (reduced from $€ 16.0$ million to $€ 6.8$ million) and an increase in accumulated losses from $€ 50.1$ million to $€ 59.4$ million between 2019 and 2020 .

The full impact of the fall in passenger journeys was mitigated by the government providing support (through the NTA) to compensate 
for losses on all direct award contracts for PSO services. In addition, the impact on revenues was mitigated by the continuation and expansion of Schools Transport Scheme services. Losses on Expressway services were also mitigated by support provided by the NTA under the Commercial Bus Operation Direct Award. Bus Éireann also made the decision to exit loss-making Expressway routes in 2020 and 2021, and this decision was accompanied by approval of a plan which consolidated the Expressway network from eighteen routes to fourteen routes. Overall, revenues from PSO and Commercial Bus Operation Direct Award Contracts amounted to $€ 93.8$ million (compared to $€ 57.9$ million in 2019).

\section{Iarnród Éireann}

Covid-19 also resulted in an approximately 50 per cent reduction of passenger journey numbers on Iarnród Éireann services and the company recorded a reduction in revenues from operations from $€ 297$ million (2019) to $€ 144$ million (2020). The company received PSO funding of $€ 199$ million (2019: $€ 87$ million) for the operation of passenger services. This increase was for the purpose of covering the reduction in passenger revenue net of savings. Other Exchequer funding received in the year amounted to $€ 332.8$ million (2019: $€ 271.5$ million), an increase of $€ 61.3$ million, which included funding support from the Covid-19 wages support subsidy scheme and the July stimulus package introduced by the government.

In December 2021 the company finalised a contract with French company Alstom to provide a new Dart fleet, signing a $€ 318$ million deal for ninety-five carriages, in what is a record contract for the state rail company. Alstom will supply up to 750 carriages to Iarnród Éireann over ten years as part of the expansion of Dublin's Dart network, boosting its reach from $50 \mathrm{~km}$ to $150 \mathrm{~km}$ (O'Halloran, 2021d).

\section{EirGrid}

As operator of the transmission grids and the electricity market in Ireland and Northern Ireland, the EirGrid Group's revenue is primarily derived from regulated tariffs. The main revenue is the Transmission Use of System (TUoS) tariff. This is a charge payable by all users of the transmission systems in Ireland and Northern Ireland. As EirGrid's activities are mainly regulated, its reported profits vary from year to year due to over- and under-recovery of regulatory income and are corrected for in-future regulated tariffs (NewERA, 
2021). In addition, a significant element of revenue is known as 'passthrough' as it comprises regulatory tariffs which are collected on behalf of the transmission asset owners (the ESB).

Due to the regulatory nature of EirGrid's revenues, profit before tax (which fell from $€ 96$ million for 2019 to $€ 14$ million for 2020) is an unsuitable measure of financial performance. Underlying profit, which excludes the impact of over- and under-recoveries on reported profit and provides a more useful measure of financial performance, fell from $€ 22.3$ million in 2019 to $€ 18.3$ million in 2020 and the group's net gearing position remained stable (approximately 33 per cent).

EirGrid's five-year strategy (2020-5) and its redefined purpose statement 'to transform the power system for future generations' are framed by two factors - climate change and the impending transformation of the electricity sector. The strategy for 2020-5 aims at ensuring that renewable energy accounts for 70 per cent of all electricity use by 2030. In Northern Ireland SONI published its strategy for the same period, which commits it to designing a green energy system to accommodate 95 per cent renewable energy at any one time. The transition to low-carbon and renewable energy will bring major changes in how electricity is generated, bought, sold and used, such as for transport and heat. Meeting these targets will require the delivery of an increased level of interconnection, and EirGrid's two key projects, the North South Interconnector and the Celtic Interconnector (linking the Irish and French electricity grids), are designated as EU Projects of Common Interest, meaning that their successful deployment is considered an essential step towards EU goals of affordable, secure and sustainable energy.

Key issues to arise in 2021 included ongoing concerns about the security of electricity supply, driven by the closure of some peatburning power plants and the temporary shutdown of two gas-fired generators combined with low wind speeds and high demand squeezing electricity supplies during the year. Market overseers issued eight alerts between January and September warning that reserves were stretched to the point where there was an increased risk of power cuts should any other facilities be forced to close (O'Halloran, 2021b). In addition, there are growing concerns about the extraordinary growth in power demand from data centres, which could account for 27 per cent of all electricity demand by the end of the decade. This figure is based on agreed connection requests of $1,800 \mathrm{MW}$ all coming to fruition, which EirGrid has said would only happen in a worst-case or 'high-demand' scenario (Murray, 2022). 


\section{ESB}

ESB delivered an operating profit before exceptional items of $€ 616$ million in 2020, a decrease of $€ 66$ million on 2019. The company's annual report noted that, on an overall basis, Covid-19 had an approximately $€ 15$ million negative impact on operating profit primarily due to an increased provision for bad debts in the Customer Solutions Division. Profit after tax of $€ 126$ million was down from $€ 338$ million recorded in 2019 . This reduction was largely attributable to exceptional items of $€ 247$ million compared to $€ 94$ million in 2019. These items included an impairment charge of $€ 188$ million on the Carrington Combined Cycle Plant for Gas Generation asset in Great Britain due to projected reductions in thermal margins and lower forecast peak prices. The company reported a healthy liquidity position of $€ 1.8$ billion in 2020 . Net debt reduced to $€ 5.2$ billion (2019: $€ 5.1$ billion) and a moderate gearing level of 55 per cent was recorded at the end of 2020. The company targets an annual dividend of 40 per cent of adjusted profits after tax and a dividend of $€ 81$ million was paid in 2020 (2019: €43 million).

ESB invested just over $€ 1.1$ billion of capital expenditure in 2020 (2019: €947 million). Almost 80 per cent of this was invested in the company's two networks businesses, including $€ 110$ million on smart metering roll-out in the Republic of Ireland. As part of the ongoing transition to low-carbon generation, ESB invested approximately $€ 57$ million in renewable generation projects, including the 50 per cent acquisition of the Inch Cape offshore wind farm (UK) project.

ESB's Brighter Future Strategy targets an accelerated transition to low-carbon electricity. It exited peat generation at the end of 2020 and will exit coal generation by the mid decade. ESB's target is to halve the carbon intensity of its electricity generation by 2030 and to bring renewable electricity output to 50 per cent of ESB's total electricity production by the same date. The company projects a sustained high level of capital investment, averaging $€ 1$ billion per annum to 2030, in smart networks, low-carbon and renewable generation, and customer offerings focused on distributed energy and digital technologies (ESB, 2021).

\section{Irish Water}

Irish Water is part of Ervia Group (along with Gas Networks Ireland and Aurora Telecom). Due to its share ownership structure, it is not a 
subsidiary of Ervia for accounting purposes. However, in governance terms the Ervia board and executive team are responsible for the performance of Irish Water (NewERA, 2021). These arrangements will remain in place until Irish Water is established as a stand-alone, publicly owned, commercial, regulated utility in 2023.

Irish Water is regulated by the Commission for Regulation of Utilities (CRU) and is also subject to regulation in respect of water quality by the Environmental Protection Agency. Irish Water's current revenue control (known as RC3) sets out its allowances for capital and operating expenditure, the revenues it is allowed to recover from customers, together with the agreed outcomes and outputs the company is responsible for delivering over the period. RC3 targets efficiency challenges averaging 4 per cent and 3 per cent per annum for operating and capital expenditure, respectively, over the 2020 to 2024 period (NewERA, 2021). In August 2020 the CRU published an updated RC 3.5 (CRU/20/085), allowing for capital investment of $€ 5.4$ billion in infrastructure and assets from 2020 to 2024.

The financial performance of Irish Water was impacted by Covid19 through lower revenues from non-domestic customers that arose from the implementation of the necessary health and safety measures. Commercial revenues of $€ 246$ million were $€ 20$ million lower than the level recorded in 2019. In addition, government subvention income of $€ 815$ million was $€ 40$ million lower due to a reduction in allowed revenues. Irish Water reported profits before income tax of $€ 121$ million in 2020 (compared to $€ 262$ million in 2019). At the end of 2020 the company held total assets of just over $€ 4.5$ billion and its net debts stood at $€ 191$ million.

Capital investment of $€ 846$ million ( $€ 836$ million in 2019) brought total investment in public water and wastewater services between 1 January 2014 to end 2020 to circa $€ 4.5$ billion. According to its 2020 annual report, Irish Water is currently managing a portfolio of over 300 capital projects and 40 national programmes. The company indicates it has delivered significant improvements since 2014, 'eliminating long-term boil water notices, ending up to half of all discharges of untreated wastewater into open water bodies and delivering higher quality and new capacity for drinking water and wastewater treatment' (Irish Water, 2021, p. 9).

Notwithstanding these improvements, the company has been heavily criticised for delays in rolling out water treatment works. In November 2021 the Environmental Protection Agency reported that thirty-four towns and villages continue to release raw sewage into the 
water course. Moreover, it stated that Irish Water had 'no clear plan' to stop these discharges and the company acknowledged it is behind schedule in rolling out water treatment works (McGreevy, 2021). In addition, the Water Advisory Board (WAB) expressed serious concerns about two significant incidents that affected drinking water in August of 2021 in the Ballymore Eustace and Gorey drinking water treatment plants. The WAB was 'particularly concerned by the failings highlighted by these incidents, the risk to public health and failures in communication and escalation and Irish Water's lack of oversight of drinking water plants' (WAB, 2021).

\section{Gas Networks Ireland}

Gas Networks Ireland (GNI) is a 100 per cent owned subsidiary of Ervia. The company owns, operates, builds and maintains the transmission and distribution gas network of $14,617 \mathrm{~km}$ of pipelines, including two sub-sea interconnectors and pipelines in Scotland, Northern Ireland and the Isle of Man. GNI's 2020 annual report indicates that despite the various challenges faced due to Covid-19, it did not have a material impact on financial performance for the year. Revenue for the year was $€ 447$ million (2019: $€ 470$ million) and profit after tax was $€ 94$ million (2019: $€ 109$ million). The group had total assets of $€ 2.7$ billion (2019: $€ 2.8$ billion) and liabilities of $€ 1.6$ billion (2019: €1.7 billion) at year end. At the end of 2020 borrowings and other debt stood at $€ 1.02$ billion ( $€ 1.15$ billion in 2019).

Ervia/GNI aims to decarbonise the gas network by 2050 as set out in its Vision 2050 publication (published in 2019). According to NewERA (2021), the company is progressing a range of climate mitigation technologies. It has established compressed natural gas as an alternative fuel source for heavy goods vehicles and is also exploring the feasibility of carbon capture and storage and the feasibility of hydrogen technologies for integration into the gas grid.

\section{Dublin Airport Authority}

The Dublin Airport Authority (DAA) incurred the highest operating loss of any SOE in 2020, with passenger numbers decimated as a result of pandemic restrictions. Turnover amounted to just $€ 291$ million (69 per cent lower than the $€ 935$ million recorded in 2019), with passenger numbers for the year amounting to 7.9 million (compared to over 32 million in 2019). The severity of the impact of the pandemic in 
early 2020 is illustrated by the fact that during the summer of 2019 Dublin Airport had flights to over 190 destinations in 42 countries operated by almost 50 airlines, whereas in April 2020 there were flights to just 22 destinations in 11 countries operated by 7 airlines (DAA, 2021). The company had to take drastic steps in order to adjust to its new operating environment, putting most employees on a fourday week in April 2020 as well as a voluntary severance scheme which saw over 900 Irish-based employees leave the company and approximately 1,000 employees leave the DAA's travel retail business overseas. While passenger numbers recovered in 2021, they were projected to only reach approximately 16 million, with the DAA estimating that it could take up to five years before a return to preCovid levels of traffic (O'Halloran, 2021a).

Cork Airport closed for ten weeks in September 2021 in order to allow for $\mathrm{a} € 10$ million refurbishment of its main runway to be fasttracked. The airport reopened at the end of November 2021 and is expecting to handle 1.8 million passengers in 2022 (approximately 70 per cent of its peak), which will be the sixtieth anniversary of the opening of the airport (Roche, 2021). Dublin Airport continues to progress the construction of its new north runway, which is due to open in 2022. Once open, it is likely that the new runway will have to close between the hours of midnight and 6 a.m. in order to limit noise (O'Halloran, 2021e). Whether the DAA can return to profitability in 2022 will depend on how quickly restrictions related to the Omicron variant of Covid are lifted and whether any new variants emerge over the course of the year.

\section{Bord na Móna}

After a number of loss-making years, Bord na Móna (BnM) recorded its first year of profits since 2017, an impressive turnaround given the substantial changes the company is undergoing as part of its 'brown to green' transition away from traditional peat-related activities. Despite a significant drop in turnover as a result of the company ending all peat harvesting on its lands in 2020, BnM still recorded strong operating profits due to a considerable reduction in the cost of sales. No further exceptional costs related to restructuring were incurred in 2020 (the company recorded over $€ 150$ million in exceptional costs in the previous two financial years), leading to a net profit of $€ 22.4$ million. 
$\mathrm{BnM}$ is increasingly set to become a major part of the national strategy to cut the country's carbon emissions in half by 2030. Apart from the company's considerable ongoing investment in the development of wind farms, the restoration of thousands of acres of peatland in the midlands will play a crucial role in meeting Ireland's carbon targets. The government has contributed $€ 108$ million through its Just Transition Fund to the peatland rehabilitation project (with BnM contributing a further $€ 18$ million), which will protect the storage of 100 million tonnes of $\mathrm{CO}_{2}$ emissions.

\section{An Post}

After having recorded profits in the previous three financial years, An Post returned to the loss-making that has characterised much of its performance over the past decade. While traditional mail volumes continued to decline during 2020, the rise in e-commerce during the pandemic led to a 100 per cent increase in parcel volumes and overall revenue for the year increased by over $€ 23$ million compared to 2019. However, at the same time, operating costs jumped by over $€ 70$ million, leading to an operating loss of $€ 10.7$ million in 2020. Much of this increase in cost was driven by pandemic-related factors such as personal protective equipment costs, replacement staff costs and a postponed increase in stamp prices.

In June 2021 An Post announced its Green Light programme, a new five-year investment plan which will see investment of $€ 200-300$ million in the company's physical and digital infrastructure. A significant proportion of the investment will be targeted at upgrading postal sorting facilities to better handle increased parcel volumes. The company also plans to invest heavily in its digital platforms to help grow its e-commerce and banking business.

\section{RTÉ}

RTÉ was excluded from our analysis last year (Palcic \& Reeves, 2021) due to a delay in the publication of its 2019 results. Having incurred operating and net losses in 2019, the broadcaster recorded a surplus for the 2020 financial year despite a considerable reduction in commercial revenues. The key factor underpinning the profitability of the firm in 2020 was an appreciable fall in operating costs due to curtailed production activity and sports events during the pandemic. Worryingly for RTÉ, licence fee income declined significantly but was 
offset by $€ 9.2$ million in additional funding from the government announced as part of Budget 2019.

A report commissioned by the Broadcasting Authority of Ireland (BAI) to examine the performance of RTÉ and TG4 was submitted to the government in August 2021. The report highlighted how radical restructuring of RTÉ will be necessary if it is not allocated a significant increase in public funding, which has been recommended by the BAI since 2018. The funding gap between the recommended funding by the BAI and actual funding for the 2018-22 period had reached $€ 46.8$ million by the end of 2019 according to the report (Bray, 2021). Separately, a report prepared by the recently established Future of Media Commission into the future of public service broadcasting funding, which was submitted to the government in October 2021, has yet to be published. A key issue arising from this report will be how the government proceeds with a reform of the TV licensing system and the future funding of RTÉ. The broadcaster claims that the current system is now costing them $€ 65$ million a year in uncollected TV licence fees due to a combination of licence fee evasion and the fact that approximately 15 per cent of households do not have a TV but still consume RTÉ content on other devices (Slattery, 2022).

\section{Coillte}

Coillte endured a difficult trading year during 2020, which saw turnover, operating profits and net profits all decline significantly compared to 2019. The deterioration in the financial performance of the company was driven by a combination of continued uncertainty surrounding Brexit, a decline in demand for wood products due to pandemic restrictions on construction activity and, critically, a forestry licensing crisis. The latter issue saw severe delays in the processing of forestry licences due to the introduction of a new regulatory regime by the Department of Agriculture, Food and the Marine, leading to significant shortages in the supply of sawlog and timber products. Given the volatile operating environment Coillte faced during 2020, the company did remarkably well to still record operating and net profits for the year.

Outside of its financial performance, Coillte continued to make major contributions to Irish society and the environment during 2020. During the various lockdown phases of the pandemic, the number of visitors to Coillte forest parks and recreation forests more than doubled, with the top fifty forests seeing an approximate 40 per cent 
increase in visits to 2.2 million (Coillte, 2021). In terms of its environmental impact, Coillte planted a record 22 million trees on over 9,000 hectares of forests in 2020 as part of its replanting strategy. In addition, the company continued to progress its renewable energy investment programme. In November 2021 Coillte's joint venture with the ESB, FuturEnergy, was formally launched with plans to build between fifteen and twenty wind farms with a total capacity of $1 \mathrm{GW}$ of power on Coillte lands across Ireland. The total investment required is estimated to be about $€ 1$ billion and the joint venture will start seeking funding from investors during 2022 (O’Halloran, 2021c).

\section{References}

Bray, J. (2021, 3 August). RTÉ faces 'existential' financial crisis, government told. The Irish Times.

CIÉ Group. (2021). CIÉ Group annual report year ended 31 December 2020. Dublin: CIÉ Group.

Coillte. (2021). Annual report 2020: Our forests. Dublin: Coillte.

Dublin Airport Authority. (2021). Annual report 2020: A year like no other. Dublin: Dublin Airport Authority.

ESB. (2021). Annual report and financial statements 2020. Dublin: ESB.

Irish Water. (2021). Annual report and financial statements 2020. Dublin: Irish Water.

McGreevy, R. (2021, 5 November). Irish Water highlights need for investment in infrastructure, while behind schedule. The Irish Times.

Murray, D. (2022, 9 January). Eirgrid finally moves to curb over-demand on energy supplies. Sunday Business Post.

NewERA. (2021). Annual financial review 2019/20. Dublin: National Treasury Management Agency.

O'Halloran, B. (2021a, 20 October). DAA warns Dublin Airport could take five years to recover pre-Covid traffic. The Irish Times.

O'Halloran, B. (2021b, 20 November). Eirgrid lines up power companies to provide emergency electricity. The Irish Times.

O'Halloran, B. (2021c, 30 November). ESB and Coillte joint energy venture to seek investors. The Irish Times.

O'Halloran, B. (2021d, 13 December). Iarnród Éireann signs deal for 750 new Dart carriages to expand services. The Irish Times.

O'Halloran, B. (2021e, 11 November). Move to close Dublin Airport's new runway from $12 \mathrm{am}$ to $6 \mathrm{am}$ to limit noise. The Irish Times.

Palcic, D., \& Reeves, E. (2018). State-owned enterprise sector, 2017. Administration, 66 (1), 59-68.

Palcic, D., \& Reeves, E. (2019). State-owned enterprise sector, 2018. Administration, 67 (1), 51-8. 
Palcic, D., \& Reeves, E. (2020). State-owned enterprise sector, 2019. Administration, 68 (1), 67-79.

Palcic, D., \& Reeves, E. (2021). State-owned enterprise sector, 2020. Administration, 69 (1), 85-95

Roche, B. (2021, 18 October). Cork Airport to complete runway refurb next month, says Coveney. The Irish Times.

Slattery, L. (2022, 18 January). RTÉ raises its estimate of 'lost' licence funding to $€ 65 \mathrm{~m}$. The Irish Times.

Water Advisory Board. (2021). Water Advisory Body publishes latest report on Irish Water [press release]. Dublin: Water Advisory Board. 